\title{
Performance Investigation of Solar Still Integrated to Solar Pond
}

\author{
Md. Irfan Ali, Bijo Joseph, R. Karthikeyan, and R. Yuvaraj
}

\begin{abstract}
This paper presents the experimental studies done on a solar still integrated to the solar-pond. The solar still base was coated with granular activated carbon(GAC) for enhancing the evaporation rate. The solar-pond was used to pre-heat the inlet water supplied to solar still. $0.01 \mathrm{~m}$ water depth was maintained in the solar still. Physical modelling of solar-pond was done in matlab to determine the optimum salinity level required for the bottom layer of solar-pond which is the heat storing zone. From the simulated results we found that $50 \mathrm{~g} / \mathrm{Kg}$ salinity is the optimal value that should be maintained at the bottom layer of the solar-pond.
\end{abstract}

Keywords--- Granular Activated Carbon (GAC), Renewable Energy, Solar-Pond, Solar Still

\section{INTRODUCTION}

W ATER is the essential element of life, without water there is no life. Because of increasing population and human activities the water is getting depleted and polluted. In future we should depend on oceanic and brackish water resources for fulfilling our demand of water. One such technique which we learnt from nature is the desalination of water using solar energy. But the efficiency is low, to increase the efficiency of solar desalination various techniques like preheating the inlet water to solar still, coating the base of the solar still using photo-catalyst elements are adopted. One such attempt to enhance the efficiency of solar still is done here.

Solar pond is an artificially constructed pond in which significant temperature rises are caused to occur in the lower regions by preventing convection. To prevent convection, salt water is used in the pond. Those ponds are called "salt gradient solar pond". In the last 15 years, many salt gradient solar ponds varying in size from a few hundred to a few thousand square meters of surface area have been built in a number of countries. Nowadays, mini solar ponds are also being constructed for various thermal applications.

The use of solar energy in desalination process is one of the most promising applications of the renewable energies. Nature is carrying out the process of water desalination since

Md. Irfan Ali, Energy Engineering, SRM University, Chennai, India, Email: irfanalimech@gmail.com

Bijo Joseph, SRM University, Chennai, India, Email:bijopedia@gmail.com

Karthikeyan, SRM University, Chennai, India, E-mail: karthijamu@gmail.com

R. Yuvaraj, Assistant Professor, Mechanical Engineering, SRM University, Chennai, India, E-mail: yuvaraj77@gmail.com ages, since Oceanic water due to solar heating converts into vapors and pours down as precipitation on earth in the form of fresh water. Here we used solar still for solar desalination process to process the saline water.

A number of efforts have been made to develop and improve the performance of solar desalination systems, particularly solar stills. The efficiency of the still is directly proportional to the inlet water temperature to still. To increase the temperature of the water inside the still, some researches $[2,4]$ suggested coupling the still to solar collectors. The results showed an improvement in the still's performance. One of the main reasons behind the low efficiency of solar stills, which is about $30-40 \%$ [1], is the loss latent heat of condensation to the environment and the sensible heat carried away by the condensate. The use of latent heat of condensation to preheat the feed water has shown good improvement in the still's performance [5,6]. The use of latent heat of condensation of one stage to evaporate water in another stage, as in multi-effect stills, has been studied by many researchers showing very good improvement in the still's performance [7, 8]. Other researchers $[9,10]$ have investigated the concept of evaporation at low temperatures under vacuum conditions and reported good improvement in the system performance. However they used vacuum pumps which require additional energy input to the system.

In this work, we have combined the solar pond and solar desalination technology. Here, the Saline water is circulated through the pond to absorb the available heat energy in the pond, then the preheated saline water is send to the solar still for evaporation by the radiant heat in the still. Matlab-R2008 software was used to simulate the model. A physical model of solar pond was built in matlab to find the optimum salinity in bottom layer of the solar-pond.

\section{Mathematical Modelling}

\section{A. Mathematical Modeling of Solar-Pond}

In salt-gradient solar-pond there are three zones, 1) upper convective zone (UCZ), it consists of fresh water, 2) nonconvective zone (NCZ) the salinity gradually increases, 3) lower convective zone (LCZ) the salinity is maintained at $50 \mathrm{~g} / \mathrm{Kg}$ for the experimental analysis. In this paper only the LCZ is considered where the sensible energy is stored.

A salt-gradient solar-pond collects and stores solarinsolation as heat in single unit. The stability of the solar-pond is normally maintained by the presence of the salt when exposed to solar insolation for heating.

Following assumptions were made, both the UCZ and LCZ zones have uniform and constant temperatures and salt concentrations, whereas the temperature and the salt- 
concentration increase with depth in the NCZ layer. In the steady-state[13] :

Rate of heat input $=$ Rate of heat stored in the $\mathrm{LCZ}+$ rate of heat losses,

$$
\text { i.e. } \mathrm{Q}_{\text {in }}=\mathrm{Q}_{\text {stored }}+\mathrm{Q}_{\text {lost }}
$$

The temperature of the stored zone (LCZ) at the end of the period, $\mathrm{T}_{\mathrm{t}+\mathrm{dt}}$ is

$$
\mathrm{T}_{\mathrm{t}+\mathrm{dt}}=\left\{\mathrm{A}_{\mathrm{s}}\left[\mathrm{h}_{(\mathrm{z})} \mathrm{I}_{\mathrm{g}}+\left(\mathrm{k}_{\mathrm{w}} \mathrm{T}_{\mathrm{a}} / \mathrm{d}_{\mathrm{ncz}}\right)\right]+\left[\mathrm{mC}_{\mathrm{p}} \mathrm{T}_{\mathrm{t}} / \mathrm{dt}\right]\right\} /\left\{\left[\mathrm{mC}_{\mathrm{p}} / \mathrm{dt}\right]+\left[\mathrm{A}_{\mathrm{s}} \mathrm{k}_{\mathrm{w}} / \mathrm{d}_{\mathrm{nc}}\right.\right.
$$

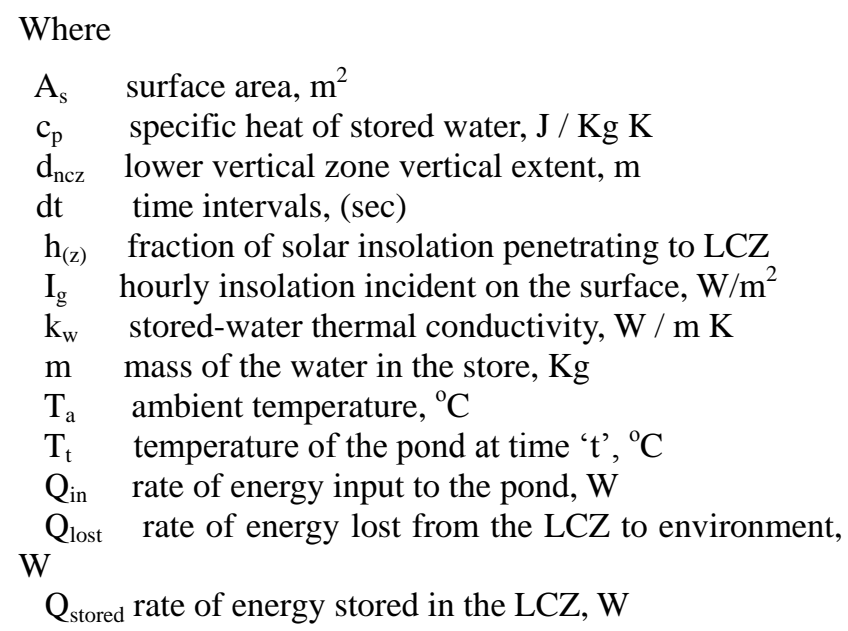

The fraction of solar radiation penetrating to the depth ' $\mathrm{z}$ ' in the pond is taken as 0.7. Specific heat of the saline water, $\mathrm{C}_{\mathrm{pw}}$ is calculated from [5] :

$$
\begin{aligned}
& \quad \mathrm{C}_{\mathrm{pw}}=\mathrm{a}_{1}+\mathrm{a}_{2} \mathrm{~T}_{\mathrm{w}}+\mathrm{a}_{3} \mathrm{~T}_{\mathrm{w}}{ }^{2}+\mathrm{a}_{4} \mathrm{~T}_{\mathrm{w}}{ }^{3} \\
& \text { and } \\
& \mathrm{a}_{1}=4.206-6.6197 \mathrm{~s}+1.2288 * 10^{-2} \mathrm{~s}^{2} \\
& \mathrm{a}_{2}=-1.1262+5.4178 * 10^{-2} \mathrm{~s}-2.2719 * 10^{-4} \mathrm{~s}^{2} \\
& \mathrm{a}_{3}=1.2026 * 10^{-2}-5.5366^{*} 10^{-4} \mathrm{~s}+1.8906 * 10^{-6} \mathrm{~s}^{2} \\
& \mathrm{a}_{4}=6.8774 * 10^{-7}+1.517 * 10^{-6} \mathrm{~s}-4.4268 * 10^{-9} \mathrm{~s}^{2}
\end{aligned}
$$

where ' $\mathrm{s}$ ' is the salinity of the $\mathrm{LCZ}$ in $\mathrm{g} / \mathrm{Kg}$.

The effectiveness of the copper heat exchanger is taken as 0.9 . The vertical distant $\left(d_{\text {ncz }}\right)$ of the NCZ is 0.9 . The water passing through the copper heat exchanger gets heated up due to the heat stored in the LCZ. For every time interval dt, the change in saline water temperature is taken as the sum of initial temperature (ambient temperature in the case of first iteration) and the temperature difference obtained from Eq.(1). Like that every time interval the change in temperature is calculated.

\section{B. Pond Efficiency}

The thermal effectiveness, $\eta_{\mathrm{p}}$, of solar pond can be defined as the ratio of the useful energy stored to the amount of insolation transmitted to the LCZ of the pond, both in the same period, dt.

$$
\eta_{\mathrm{p}}=\left[\left(\mathrm{mC}_{\mathrm{p}} / \mathrm{dt}\right) *\left(\mathrm{~T}_{\mathrm{t}+\mathrm{dt}}-\mathrm{T}_{\mathrm{t}}\right)\right] /\left[\mathrm{A}_{\mathrm{s}} \mathrm{I}_{\mathrm{g}} \mathrm{h}_{(\mathrm{z})}\right]
$$

\section{Solar Still}

Performance of solar still based on productivity, efficiency as well as internal heat and mass transfer coefficient. Hence performance of solar still is directly proportional to internal heat transfer coefficients. Internal heat and mass transfer coefficient in the solar still based on three parameters called convection, radiation and evaporation, hence there are three heat transfer coefficient called convective heat transfer coefficient, radiative heat transfer coefficient and evaporative heat transfer coefficient. To increase the efficiency of solar still the evaporation rate should be increased and convective, radiative losses should be minimised [12].

\section{i. Convective Heat Transfer}

One of the major losses in the still are convective losses, these have to be minimised to increase the efficiency of the still. Action of buoyancy force plays a major role it is because of density difference of humid air, this is because of temperature difference of the water and glass surfaces, leading to the convective heat transfer in solar still. The convective heat transfer coefficient of water surface to condensing glass cover is given by:

$\mathrm{q}_{\mathrm{cw}}=\mathrm{h}_{\mathrm{cw}}\left(\mathrm{T}_{\mathrm{g}}-\mathrm{T}_{\mathrm{a}}\right)$

Heat transfer coefficient $h_{c w}$ can be calculate by following equation

$\mathrm{h}_{\mathrm{cw}}=0.884\left[\left(\mathrm{~T}_{\mathrm{w}}-\mathrm{T}_{\mathrm{g})}+\left(\left(\mathrm{P}_{\mathrm{w}}-\mathrm{P}_{\mathrm{g}}\right)\left(\mathrm{T}_{\mathrm{w}}+273.15\right) /\left(268.9 \times 10^{-3} \mathrm{P}_{\mathrm{w}}\right)\right)\right]\right.$ where

$\mathrm{h}$ cw Convective heat transfer coefficient from water to cover, $\mathrm{W} / \mathrm{m} 2 /{ }^{\circ} \mathrm{C}$

$\mathrm{h}_{\mathrm{w}}$ Convective heat transfer coefficient from basin liner to water, $\mathrm{W} / \mathrm{m} 2 /{ }^{\circ} \mathrm{C}$

$\mathrm{P}_{\mathrm{g}} \quad$ Partial pressure at cover temperature, $\mathrm{N} / \mathrm{m}^{2}$

$P_{w}$ Partial pressure at basin water temperature, $N / \mathrm{m}^{2}$

$\mathrm{q}_{\mathrm{cw}}$ Convective heat transfer from water to cover, $\mathrm{W} / \mathrm{m}^{2}$

$\mathrm{T}_{\mathrm{a}}$ Ambient temperature, ${ }^{\circ} \mathrm{C}$

$\mathrm{T}_{\mathrm{g}}$ Cover temperature, ${ }^{\circ} \mathrm{C}$

$\mathrm{T}_{\mathrm{w}} \quad$ Basin water temperature, ${ }^{\circ} \mathrm{C}$

\section{ii. Radiative Heat Transfer}

Basin water is always at a higher temperature than cooling glass surface, due to this radiation is occurring between the two surfaces, resulting in the loss of input solar radiation. Rate of radiative heat transfer from water surface to condensing cover is given by:

$$
\mathrm{q}_{\mathrm{rw}}=\mathrm{h}_{\mathrm{rw}}\left(\mathrm{T}_{\mathrm{w}}-\mathrm{T}_{\mathrm{g}}\right)
$$

Radiative heat transfer coefficient $r w h$ is given by:

$$
\mathrm{h}_{\mathrm{rw}}=\varepsilon_{\text {effect }} \sigma\left[\left(\mathrm{T}_{\mathrm{w}}\right)^{2}+\left(\mathrm{T}_{\mathrm{g}}\right)^{2}\right] /\left(\mathrm{T}_{\mathrm{w}}-\mathrm{T}_{\mathrm{g}}\right)
$$

Here

$$
\begin{aligned}
& \sigma=5.669 \times 10^{-8} \mathrm{~W} / \mathrm{m}^{2} \mathrm{~K}^{4} \\
& \varepsilon_{\text {effect }}=\left(1 / \varepsilon_{\mathrm{w}}+1 / \varepsilon_{\mathrm{v}}-1\right)^{-1} \\
& \varepsilon_{\mathrm{w}}=\varepsilon_{\mathrm{g}}=0.9
\end{aligned}
$$

$\mathrm{h}_{\mathrm{rb}}$ Radiative heat transfer coefficient from bottom insulation to ambient, $\mathrm{W} / \mathrm{m}^{2} /{ }^{\circ} \mathrm{C}$

$h_{\mathrm{rw}}$ Radiative heat transfer coefficient from water to cover, $\mathrm{m}^{2} /{ }^{\circ} \mathrm{C}$

$\mathrm{q}_{\mathrm{rw}}$ Radiative heat transfer from water to cover, $\mathrm{W} / \mathrm{m}^{2}$ 


\section{iii. Evaporative Heat Transfer}

Any one working on solar still always tries to increase the convection rate by various means. When solar energy is incident inside the solar still, water evaporates and converted into steam.

Hence, evaporative heat transfer is given by following equation

$$
\begin{aligned}
& \mathrm{q}_{\mathrm{ew}}=\mathrm{h}_{\mathrm{ew}}\left(\mathrm{T}_{\mathrm{w}}-\mathrm{T}_{\mathrm{g}}\right) \\
& \text { Evaporative heat transfer coefficient is given by }
\end{aligned}
$$

$$
\mathrm{h}_{\text {evp }}=16.273 \times 10^{-3} \mathrm{~h}_{\mathrm{cw}}\left[\left(\mathrm{p}_{\mathrm{w}}-\mathrm{p}_{\mathrm{g}}\right) /\left(\mathrm{T}_{\mathrm{w}}-\mathrm{T}_{\mathrm{g}}\right)\right]
$$

Total heat transfer coefficient from water surface to condensing cover is given by following equation

$\mathrm{h}_{1 \mathrm{w}}=\mathrm{h}_{\mathrm{cw}}+\mathrm{h}_{\mathrm{rw}}+\mathrm{h}_{\mathrm{ew}}$

$\mathrm{h}_{\mathrm{ew}}$ Evaporative heat transfer coefficient from water to cover, $\mathrm{W} / \mathrm{m}{ }^{2} /{ }^{\circ} \mathrm{C}$

$\mathrm{h}_{1 \mathrm{w}}$ Total heat transfer coefficient from water to cover, $\mathrm{W} / \mathrm{m}^{2}$ / ${ }^{\circ} \mathrm{C}$

$\mathrm{h}_{1 \mathrm{~g}}$ Total heat transfer coefficient from cover to atmosphere, $\mathrm{W} / \mathrm{m}^{2} /{ }^{\circ} \mathrm{C}$

\section{iv. Energy Balance in Solar Still}

When solar energy is incident on the basin water, heat and mass transfer mechanisms start inside the still. In figure 1 shows the energy flow in double slope single basin solar still. Energy balance equation can be written with following assumption

1. There is no vapour leakage in solar still

2. It is an air tight basin, hence no heat loss.

3. Heat capacity of cover and absorbing material, insulation is negligible.

4. There is no temperature gradient across the basin water and glass cover of solar still.

5. Water level inside the basin maintained at constant level.

6. Only film type condensation is occurs in place of drop type condensation.

- Energy balance for glass cover $\alpha_{\mathrm{g}} \mathrm{I}(\mathrm{t})+\left(\mathrm{q}_{\mathrm{cw}}+\mathrm{q}_{\mathrm{rw}}+\mathrm{q}_{\mathrm{ew}}\right)=\mathrm{q}_{\mathrm{rg}}+\mathrm{q}_{\mathrm{eg}}$

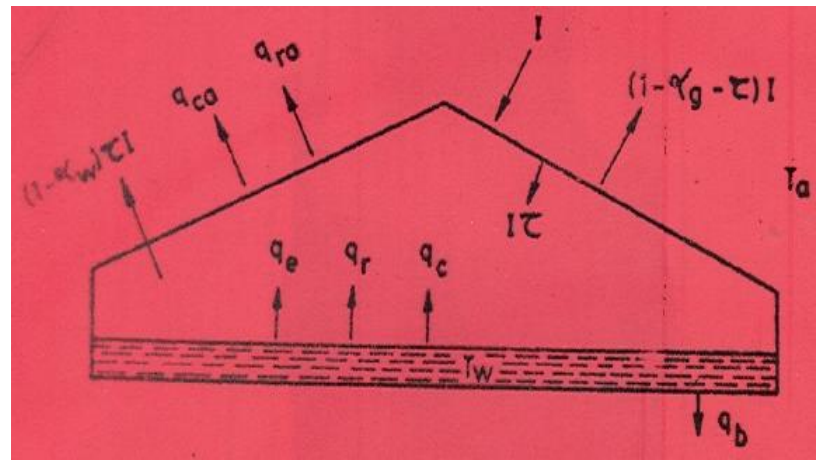

Figure 1: Energy flow in Single Basin Double Slope Solar Still

- $\quad$ Energy balance for basin water $\alpha_{b} \mathrm{I}(\mathrm{t})+\mathrm{q}_{\mathrm{w}}=(\mathrm{MC})_{\mathrm{w}}\left(\mathrm{T}_{\mathrm{w}} / \mathrm{dt}\right)+\mathrm{q}_{\mathrm{cw}}+\mathrm{q}_{\mathrm{rw}}+\mathrm{q}_{\text {ew }}$

- Energy balance for basin $\alpha_{\mathrm{b}} \mathrm{I}(\mathrm{t})=\mathrm{q}_{\mathrm{w}}+\left(\mathrm{q}_{\mathrm{cb}}+\mathrm{q}_{\mathrm{s}}\left(\mathrm{A}_{\mathrm{ss}} / \mathrm{A}_{\mathrm{s}_{-}}\right)\right.$
- Heat transfer coefficients $\mathrm{h}_{1 \mathrm{~g}}=5.7+3.8 \mathrm{~V}$

- Hourly yield of solar still is given by: $\mathrm{m}_{\mathrm{w}}=\left(\mathrm{q}_{\mathrm{ew}} / \mathrm{L}\right) \times 3600$

- Efficiency of solar still is given by $\mathrm{H}=\left(\mathrm{q}_{\mathrm{ew}} / \mathrm{I}(\mathrm{t})\right)$

Here

$\mathrm{I}(\mathrm{t}) \quad$ Total solar radiation, $\mathrm{W} / \mathrm{m}^{2}$

$\mathrm{K}_{\mathrm{i}}$ Thermal conductivity of insulating material, $\mathrm{W} / \mathrm{m} /{ }^{\circ} \mathrm{C}$

$\mathrm{L} \quad$ Latent heat of vaporization, $\mathrm{J} / \mathrm{kg}$

$\mathrm{L}_{\mathrm{i}} \quad$ Thickness of insulation, $\mathrm{m}$

$(\mathrm{MC})_{\mathrm{w}}$ Heat capacity of water mass in basin, $\mathrm{J} / \mathrm{m}^{2}$ $1{ }^{\circ} \mathrm{C}$

\section{EXPERIMENTAL SET-UP}

In figure 2 you can see the solar still integrated to solarpond. The still is maintained at $0.01 \mathrm{~m}$ water depth which is the optimum value found from the previous experiments. The base of the still is coated with granular activated carbon to enhance its evaporative efficiency. The solar-pond is made of mildsteel, $0.95 \mathrm{~m}$ height and $1.25 \mathrm{~m}$ in diameter resulting in the surface area of $1.23 \mathrm{~m}^{2}$ exposed to solar radiations. Based on the above mathematical model of solar pond, $50 \mathrm{~g} / \mathrm{Kg}$ salinity concentration was found optimal for the LCZ from the simulation done in matlab, for the given dimensions of our solar-pond. However the efficiency of the pond increases as the salinity of the LCZ increases, but this may lead to the choking of the pipes of the system.

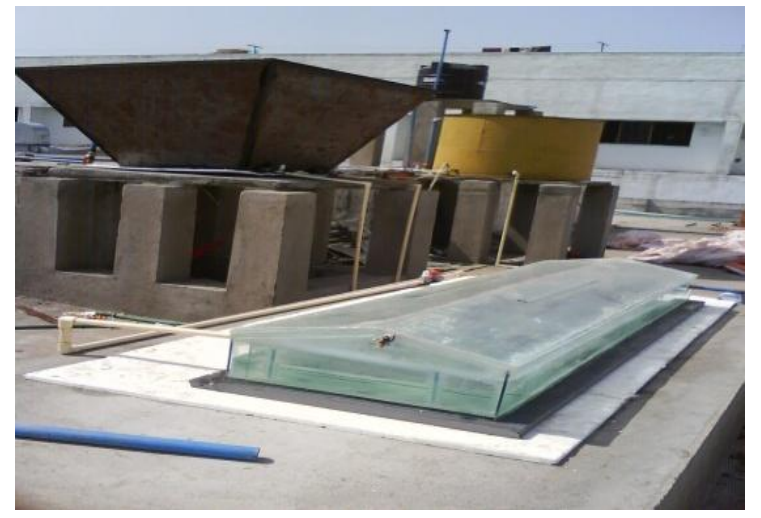

Figure 2: Solar Still Connected to Two Solar-Ponds

In this paper the study done on integration of solar still with circular solar-pond is presented. In figure 3 you can see the solar pond is perfectly insulated with glass wool fiber, and covered with glass cover to minimize the conductive and convective losses from the pond. 


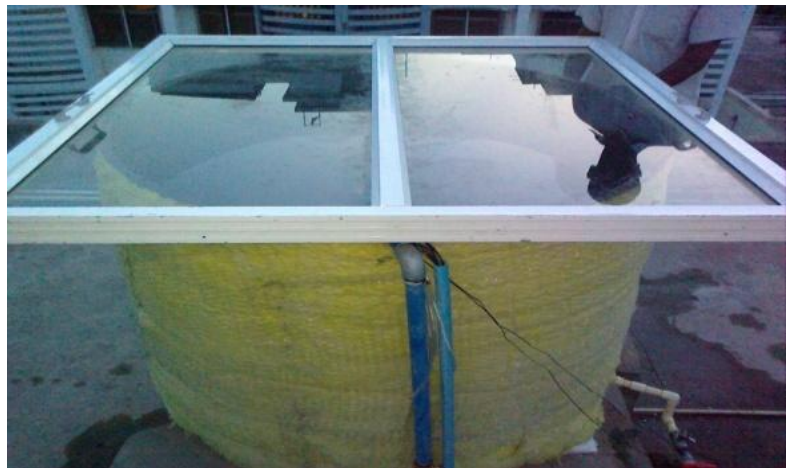

Figure 3: Solar-Pond

In figure 4 you can see the arrangement of k-type thermocouples for measuring temperature of the pond at various zones.

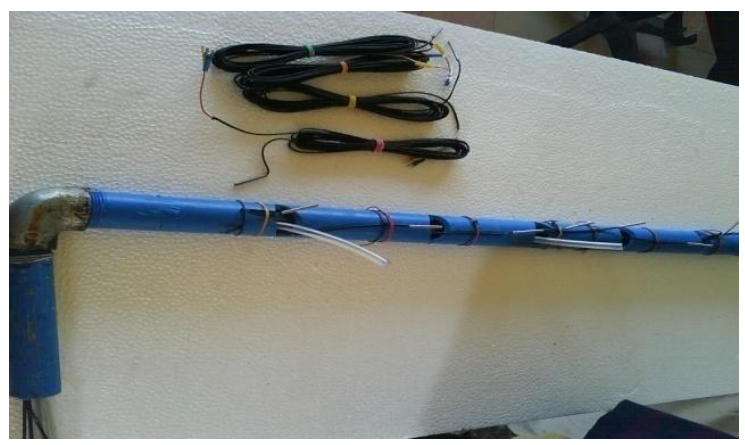

Figure 4: Arrangement of Thermocouples in the Solar-Pond

\section{RESUlTS AND Discussions}

In three ways the experiments were conducted. First the still was maintained at the depth of $0.01 \mathrm{~m}$ and experiment was conducted. After that the still's base was coated will GAC and the experiment was conducted. And at the end the coated still was connected to solar-pond and again the experiment was conducted. Theoretical values are the results obtained from the simulation done in matlab, based on the above mathematical models. Following are the results.

Table 1: Theoretical and Experimental Output From Still.

\begin{tabular}{|c|c|c|c|c|}
\hline \multirow{2}{*}{$\begin{array}{c}\text { Time } \\
(\mathrm{Hrs})\end{array}$} & \multicolumn{4}{|c|}{ Output from the still at $0.01 \mathrm{~m}$ water depth } \\
\cline { 2 - 5 } & $\mathrm{T}_{\mathrm{g}}\left({ }^{\circ} \mathrm{C}\right)$ & $\mathrm{T}_{\mathrm{w}}\left({ }^{\circ} \mathrm{C}\right)$ & $\begin{array}{c}\text { Theoretical } \\
\text { output }(\mathrm{Kg})\end{array}$ & $\begin{array}{c}\text { Experimental } \\
\text { output }(\mathrm{Kg})\end{array}$ \\
\hline $10-11$ & 18.2 & 25.6 & 0.001254 & 0.00 \\
\hline $11-12$ & 20.6 & 32.9 & 0.002664 & 0.001 \\
\hline
\end{tabular}

\begin{tabular}{|c|c|c|c|c|}
\hline $12-13$ & 22 & 37.5 & 0.005485 & 0.002 \\
\hline $13-14$ & 23.2 & 45.3 & 0.01223 & 0.009 \\
\hline $14-15$ & 23.7 & 49.2 & 0.013457 & 0.10 \\
\hline $15-16$ & 25 & 51.6 & 0.017460 & 0.013 \\
\hline $16-17$ & 26.2 & 45.5 & 0.006092 & 0.004 \\
\hline $17-18$ & 26.8 & 42.3 & 0.004431 & 0.002 \\
\hline $18-19$ & 27.5 & 38.4 & 0.004112 & 0.002 \\
\hline
\end{tabular}

Above table infers us that maximum temperature of the basin water is $51.6{ }^{\circ} \mathrm{C}$, at $3-4 \mathrm{PM}$. The output obtained from the still is $0.013 \mathrm{Kg}$.

Table 2: Output from the still when Coated with GAC

\begin{tabular}{|c|c|c|c|}
\hline $\begin{array}{c}\text { Time } \\
\text { (Hrs) }\end{array}$ & $\left.\mathrm{T}_{\mathrm{g}}{ }^{\circ} \mathrm{C}\right)$ & $\mathrm{T}_{\mathrm{w}}\left({ }^{\circ} \mathrm{C}\right)$ & $\begin{array}{c}\text { Mass of } \\
\text { distillate with } \\
\mathrm{GAC}(\mathrm{Kg})\end{array}$ \\
\hline $10-11$ & 19.3 & 31.2 & 0.02 \\
\hline $11-12$ & 21.3 & 38.3 & 0.039 \\
\hline $12-13$ & 22.4 & 43.6 & 0.120 \\
\hline $13-14$ & 24.5 & 51.2 & 0.192 \\
\hline $14-15$ & 25.1 & 54.3 & 0.269 \\
\hline $15-16$ & 26.3 & 56.1 & 0.280 \\
\hline $16-17$ & 27.4 & 51.6 & 0.220 \\
\hline $17-18$ & 28.1 & 46.2 & 0.190 \\
\hline $18-19$ & 28.9 & 40.5 & 0.103 \\
\hline
\end{tabular}

When the solar still basin was coated with GAC maximum temperature achieved is $56.1{ }^{\circ} \mathrm{C}$ and the output obtained from the still is increased to $0.28 \mathrm{Kg}$.

Table 3: Output From Still When Coated with GAC and connected to Solar-Pond

\begin{tabular}{|c|c|c|c|c|}
\hline $\begin{array}{c}\text { Time } \\
(\mathrm{Hrs})\end{array}$ & $\mathrm{T}_{\mathrm{g}}\left({ }^{\circ} \mathrm{C}\right)$ & $\mathrm{T}_{\mathrm{w}}\left({ }^{\circ} \mathrm{C}\right)$ & $\begin{array}{c}\text { Temperature } \\
\text { of water } \\
\text { coming out } \\
\text { of solar- } \\
\text { pond }\end{array}$ & $\begin{array}{c}\text { Mass of } \\
\text { distillate } \\
\text { with GAC } \\
\text { and solar- } \\
\text { pond(Kg) }\end{array}$ \\
\hline $10-11$ & 19.7 & 34.2 & 31.2 & 0.034 \\
\hline $11-12$ & 21.9 & 41.6 & 35.9 & 0.112 \\
\hline $12-13$ & 22.8 & 46.1 & 37.9 & 0.230 \\
\hline $13-14$ & 24.6 & 54.4 & 42.8 & 0.330 \\
\hline $14-15$ & 25.9 & 57.6 & 45.8 & 0.360 \\
\hline $15-16$ & 27.2 & 59.4 & 48.8 & 0.401 \\
\hline $16-17$ & 28.3 & 54.2 & 45.8 & 0.312 \\
\hline $17-18$ & 29.1 & 49.1 & 43.5 & 0.204 \\
\hline $18-19$ & 29.6 & 43.3 & 39.4 & 0.197 \\
\hline
\end{tabular}

When the GAC coated still is connected to solar-pond the maximum temperature obtained in the still is $59.4{ }^{\circ} \mathrm{C}$, and the hourly output is increased to $0.401 \mathrm{Kg}$. 


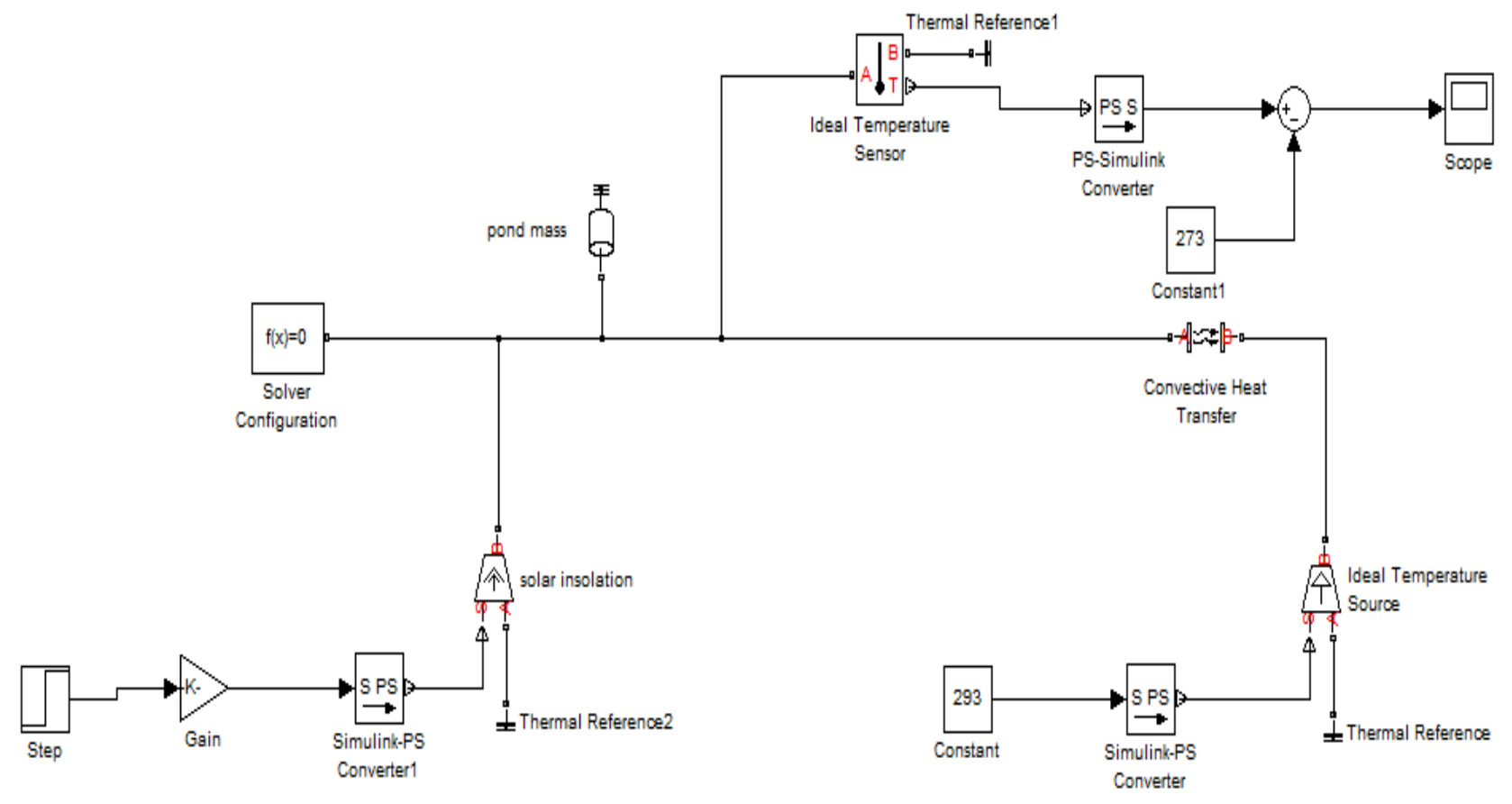

Figure 5: Physical Model of Solar-Pond in Simulink

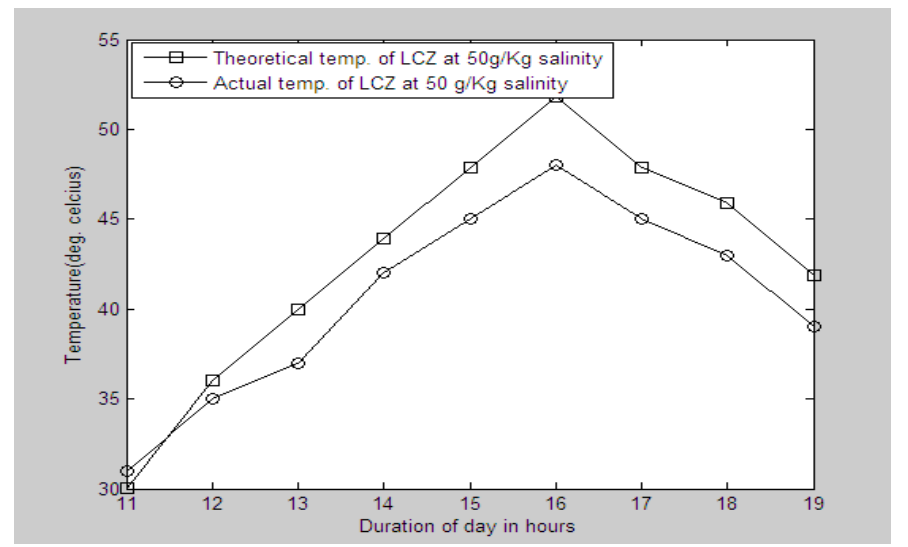

Figure 6: Theoretical and Actual Temperatures of LCZ at $50 \mathrm{~g} / \mathrm{KG}$ Salinity

Figure 5 is the physical model of solar-pond in simulink. From the simulation we obtained the optimal value of salinity of the $\mathrm{LCZ}$ to be $50 \mathrm{~g} / \mathrm{Kg}$ for the given dimensions of our pond. In figure 6 you can see the variation of temperature of LCZ with respect to time. There was not much deviation in simulated and actual results. For the given pond dimensions maximum temperature achieved is $48.8^{\circ} \mathrm{C}$.

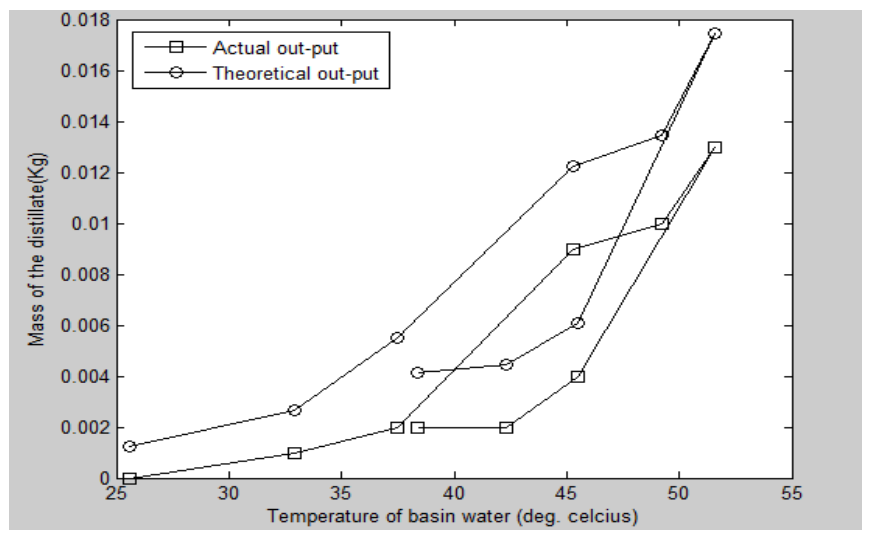

Figure 7: Theoretical and Actual Output from the Still

The above figure shows the variation of output from the still with respect to temperature of basin water. The highest hourly distillate obtained was $0.1 \mathrm{~kg}$. 


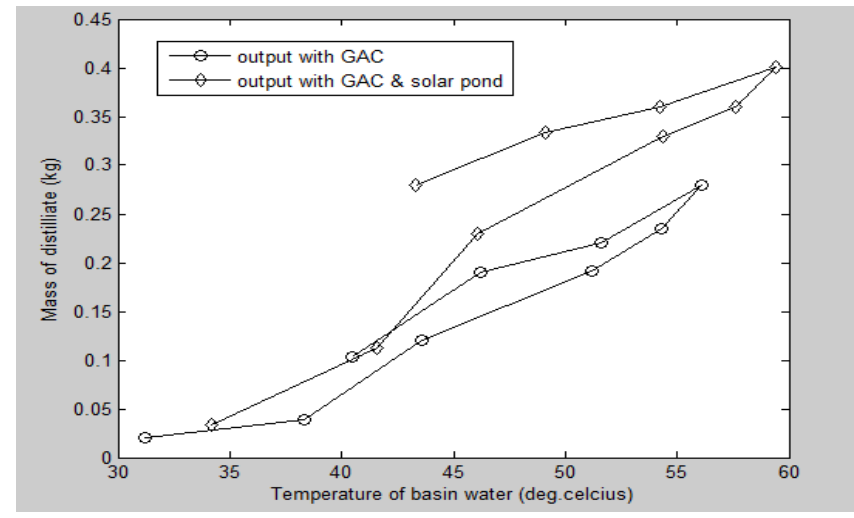

Figure 8: Variation of Output from still with GAC Coating on Still Base and with Combination of GAC And Solar-Pond with Respect to Temperature of Basin Water

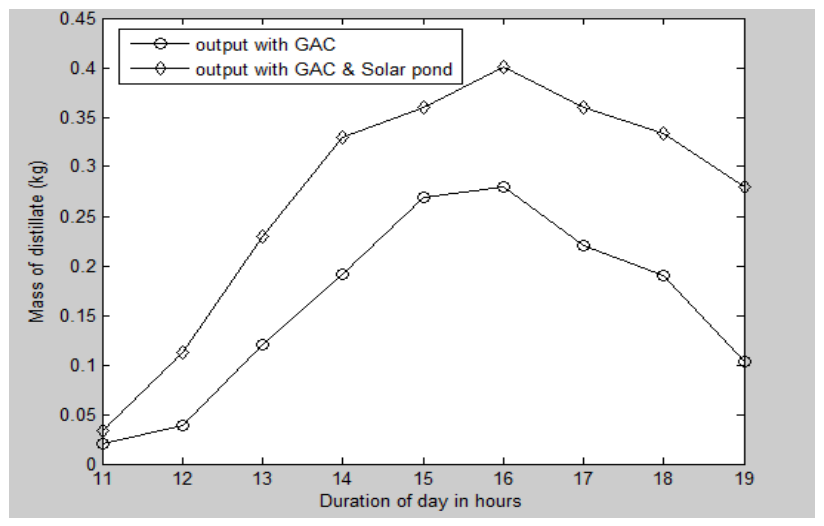

Figure 9: Variation of Output from still with GAC Coating and with combination of GAC and Solar-Pond Pre-Heating, with respect to Time

Figures 8, 9 shows the variation of output from still when coated with GAC on the solar still base, and also when coated solar still was connected to solar-pond for pre-heating the inlet water to still. When only coated solar still was used we got maximum hourly output as $0.28 \mathrm{Kg}$, but when GAC coated still was connected to solar-pond the maximum output obtained was $0.401 \mathrm{Kg}$.

\section{CONCLUSION}

The efficiency of the solar still can be increased by increasing the evaporation rate and by minimizing the convective and radiative losses in still. The evaporation rate can be increased effectively by coating the still base with photo-catalyst materials, or by pre-heating the inlet water of still. The easily available GAC is one of the best photocatalyst material suitable for the solar-still for enhancing the evaporation rate. Solar-pond technology is the renewable and efficient technology for pre-heating the inlet water to solar still. Hence by the combination of GAC coating and solarpond technology the evaporation rate can be increased considerably, hence the efficiency of solar still is increased.

\section{ACKNOWLEDGMENT}

We sincerely thank Dr. M. Cheralathan, Dr. Nikolai Khartchenko, R. Senthilkumar and Dr.John Thiruvadigal for their outstanding support and timely help at every step of our project.

\section{REFERENCES}

[1] E. Delyannis and V. Belesssiotis, "Solar energy and desalination, in: Advances in Solar Energy", An Annual Review of Research and Development, D.Y. Goswami, ed., Vol 14, American Solar Energy Society, Boulder, Colorado, Pp.287-330, 2001.

[2] S. Kumar and G.N. Tiwari, "Performance evaluation of an active solar distillation system, Energy", 21(1996) Pp. 805-808, 1996.

[3] A.A. ElSebaii, Yaghmour S.J, F.S. AlHazmi, Adel S. Faidah, F.M. AlMarzouki and A.A. AlGhamdi, "Active single basin solar still with a sensible storage medium”, Desalination 249, Pp. 699-706.

[4] N.H.A. Rahim, "New method to store heat energy in horizontal, Renewable Energy", 28, Pp. 419-433, 2003.

[5] Hiroshi Tanaka, "Experimental study of a basin type solar still with internal and external reflectors in winter", Desalination 249, Pp. 130$134,2009$.

[6] V. Velmurugan and K. Srithar, "Solar stills integrated with a mini solar pond - analytical simulation and experimental validation", Desalination 216, Pp.232-241, 2007

[7] Salah Abdallah, Mazen M. AbuKhader and Omar Badran Salah Abdallah et.al, "Effect of various absorbing materials on the thermal performance of solar stills", Desalination 242, Pp.128-137, 2009

[8] Abdul Jabbar N. Khalifa, Ahmad M. Hamood Abdul Jabbar et.al, Performance correlations for basin type solar stills, Desalination 249, Pp.24-28, 2009

[9] A.E. Kabeel, "Performance of solar still with a concave wick evaporation surface", Energy 34, Pp. 1504-1509, 2009

[10] S. Shanmugan, P. Rajamohan and D. Mutharasu, "Performance study on an acrylic mirror boosted solar distillation", Desalination 230, Pp.281287, 2008

[11] B.A. Jubran, MI. Ahmed, A.F. Ismai! and Y.A. Aba!car, Numerical modeling of a multi-stage solar still, Energy Conv. Mgmt., Vol. 41, 1107-1121, 2002.

[12] Salah Abdallah, Omar Badran and Mazen M. AbuKhader Salah Abdullah et.al, Performance evaluation of a modified design of a single slope solar still, Desalination 219, Pp. 222-230, 2008.

[13] Hitesh N Panchal and P.K. Shah, "Modelling and verification of single slope solar still using ANSYS-CFX", International Journal of Energy and Environment, Vol. 2, No. 6, 2011.

[14] M.A. Tahat, Z.H. Kodah, S.D. Probert, H. Al-Tahaineh, "Performance of potable mini solar-pond", Applied Energy, Vol. 66, Pp. 299-310, 2000.

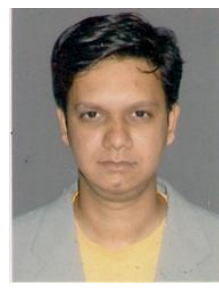

Md. Irfan Ali is doing his M.Tech in Energy Engineering from SRM University Chennai. He did his B.E in Mechanical Engineering from Muffakham Jah College of Engineering and Technology in 2010. His area of interest is applications of solar thermal energy. $\mathrm{He}$ is currently working on solar desalination system, his work involves use of different photo-catalysts and pre-heating equipments to increase the efficiency of the solar desalination system.

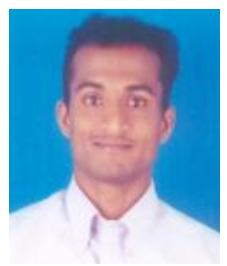

H. Bijo Joseph is doing M.S in Nano Technology from SRM University. He received his B.E. in Electrical and Electronics Engineering in Jayam College of Engineering and Technology affiliated to Anna University in 2009. His area of interest is Electronic devices. He is presently working on synthesis of silicon nano wire and its characterization. 


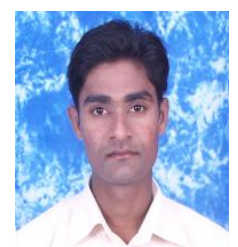

R. Karthikeyan is doing M.S in Nano Technology from SRM University. He received his B.E. in Electrical and Electronics Engineering in Jayam College of Engineering and Technology affiliated to Anna University in 2009. His area of interest is Electrical Machines and Electronic devices. $\mathrm{He}$ is presently working on Nano Electronics.

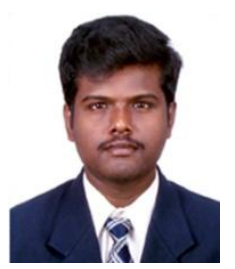

R. Yuvaraj is an Assistant Professor in SRM University. He received his M.E. in Thermal Engineering from Anna University in 2007. His area of research is IC Engine Performance Improvement \& Simulation, CFD Analysis. He previously worked as FEA Analyst in HCL Technologies Ltd., Bangalore. He was involved in FEM creation of Aeronautical parts, Design and development of surgical blades. He undertakes Thermodynamics, Thermal Engineering, Fluid Mechanics and Refrigeration and Air Conditioning courses for students. 